\title{
Kosovo's Refugees and the ED: Wherein Lies the Threat?
}

\author{
Joanne van Selm
}

\begin{abstract}
The crisis in Kosovo, which has developed over the course of a decade into a conflict involving more states than any since World War II has resulted in the displacement of almost the entire KosovarAlbanian population, as well as of a great many Serbs and other regional populations. The European Union (EU) memberstates have prided themselves on their unity of action under NATO, in tackling this crisis. However, there has been no unity of policy toward the" refugees" -in spite of the entry into force of the Treaty of Amsterdam, with its goal of 'an area of freedom security and justice' involving a common asylum and immigration policy. ${ }^{1}$ The most frequently heard arguments for the reluctance to accept Kosovars in EU states are that this would only encourage ethnic cleansing, and that EU states already have too many immigrants, asylum-seekers and refugees who will not go home. The position of the "refugees" is thus a politically difficult one, and becomes a security issue in many senses. In this article, the author explores some ideas about the nature of the nexus between refugees (and migration more generally) and security in the post-Cold War world. In doing this, she will set out to critique the writings on 'societal security' in particular, posing the key question as to where exactly the threat lies as far as refugees are concerned.

\section{Resume}

La crise du Kosovo, qui s' est d€veloppe en une decennie pour deboucher sur un conflit impliquant Ie plus grand nombre d etats depuis la Seconde Guerre Mondiale, a eu pour resultat Ie deplacement de la quasi totaliU de la population kosovarde de souche albanaise, ainsi que d'un grand nombre de serbes et autres

Dr. Joanne van Selm is a Lecturer and Researcher in International Relations at the University of Amsterdam, The Netherlands.

Refuge, Vol. 18, No.3 (August 1999) segments de population locale. Les etats membres de 1'Union Europeenne(UE) se sont glorifies de leur unite d' action sous couvert de l' aT AN lors de leur prise en charge de la crise. Cependant, il n'y a eu aucune unite de doctrine sur la question des «refugies» - et ce en depit de I' entree en vigueurdu traited'Amsterdam, avec ses objectifs de mise en place «d' une zone de liberte, de securite, et de justice» impliquant asile commun et politique d' immigration. L' argument Ie plus frequemment avance pour expliquer la resistance des etats de 1'UE a accueillir des Kosovars est celui selon lequel cela representerait un encouragement implicite a la purification ethnique. S'y ajoute l'idee selon laquelle les etats de l'UE comptent deja trap d'immigrants, de demandeurs d' asile, et de refugies qui ne rentreront plus chez eux. Consequemment la position de «refugib $>$ est uneposition politique difficile, et pose, de plusieurs points de vue, des problemes de securite. Dans Ie present article, I' auteure developpe un certain nombre de considerations sur la nature du point nodal entre refugies (et immigration, de far;on plus generale) et securite dans Ie monde de I' apres Guerre froide. Ce faisant, elle procede a la critique $d^{\prime}$ un certain nombre de travaux, notammen ceux traitant de la «securite societale», et souleve la question clef suivante: ou reside exactement la menace en ce qui concerne les refugies?

Refugees and other displaced persons face and have faced human, personal, community and societal security violations whose impact far exceeds that of any security threats faced by West Europeans since World War II. States have long agreed upon their duties and obligations to one another, and to those individualscast out into the international system. Any threatto, or violation of, the security of a person who, by virtue of this threat, becomes a refugee (someone without state protection in a world where such protection is deemed neces- sary) is, therefore, of concern to the international community. The cause of refugeehood is of concern, because the protection of the refugee is an international concern. To confront those causes, other states should, I suggest, welcome and nurture refugees as people who can survive to re-invigorate and bring back to normalcy the society of their country of origin once a security crisis is over. ${ }^{2}$ By including the excluded, most states and societies will demonstrate and reinforce their nature, or identity, as humane and dynamic. They will also promote the rejection of racism and xenophobia. The ethnic cleansing perpetrated by a leader such as Milosevic should not be echoed by ethnic exclusion, to the satisfaction of West European racists.

The literature emanating from what has been labelled "The Copenhagen School" has played a significant role in raising awareness and driving thinking in academic circles about the nexus between security and migration. ${ }^{3}$ The emerging school of thought around "societal security" and other aspects of the "new security framework" posits, in essence, that threats to identities are the basis of the new security concerns. The threa t recipient need not necessarily be the state, as has traditionally been the case in past considerations of security issues in international relations; a threat-recipient can also be another "unit," such as sub-national or transnational society. In general, however, it becomes difficult, both for the writers concerned and their readers, to distinguish between societal units and national units, or societies and states. A Shaw points out, W aever' $\mathrm{S}$ contribution on societal security in his 1993 book presents a novel and potentially highly useful sociological attitude towards security, which he no sooner developed than rejected. ${ }^{4} \mathrm{He}$ posited, citing Giddens, a distinction between society "in the generalized connotation of 'so- 
cial association' or interaction," and in the sense of " a society" with boundaries marking it off from other societies. But he then rejected both social associations and any notion of a global society, and limited himself instead to a definition of society which he wanted to complement the role of states, but which, in fact, restricted societies to being understandable only in the form of existing states. ${ }^{5}$ Since the identity of the society or state is what is at issue as the value to be protected, we are then back to a situation where "national interest" equates to "societal values" or "identity," and a static identity becomes the most precious commodity a state holds. All states being equally formed actors in the anarchical system, if of differing strength, we are back to traditional realism.

As a "problem-solving" theory, what this "new" form ofrealismis trying to do is to seek a way of understanding what the problem is with our world, and to solve it. ${ }^{6}$ One problem identified by this theory is that some features (e.g., culture, politics, religion, language) of state or societal identity (which, as was already said, is reduced to the same thing) may be challenged or threatened by the presence of others. This presupposes that identity is a static and easily recognisable feature of society. This theory also suggests that identity, equated with national security, has often been challenged by non-citizensimmigrants and refugees-in the past. Identities, attached to states, nations or societies, have surely developed over the last millenni a-often because people from other parts of the world have travelled, invaded, colonised, and/ or have moved to work or out of interest. Many people would consider this dynamic of identity a positive feature of global development, and would employ such terms as "multi-cultural," "cosmopolitan" and "globalization" to describe them. There are very few stark cases of actual, objectively identifiable threats from immigrants which do spring to mind: the World Trade Center bombers in the United States were indeed "asylum seekers," or were atleast (ab )using that entry category in order to be present in the United States. The many thou- sands of Hungarian refugees of 1956 and the Czechoslovakian refugees of 1967, were not rejected on the grounds that their presence would threaten societal security, but rather were accepted with open arms as challengers to, and people threatened by, the Communistenemy. Kosovar-Albaniansare also challengers to, and threatened by, the war criminal Milosevic and his regime: but there is no welcome orprotection for them.

Another problem one could say is (indirectly) identified by these "new" realist scholars, through a different reading of their work, is that of racism and xenophobia; however, the solution prescibed remains that immigration should be stopped. This logic suggests that if there are no immigrants, there will be no xenophobia or racism; hence, so there should be no immigrants. This logic is severely flawed, because racism and xenophobia is not caused by immigrants, but by the attitudes of existing members of the society receiving those immigrants. Jews werenotresponsible for the phenomenon we call Nazism: immigrants are similarly not responsible for the phenomenon we label racism and xenophobia. What is more, those subscribing to this notion of societal security suggest that if there are no immigrants, our identity will be unchallenged, since there will be no challenge from either the immigrants with their "other" cultures, or from those racists and xenophobes who pose enormous questions about what exactly being British, French, German, Dutch or of any other nationality signifies. I would agree that racism and xenophobia are serious threats to all societies which claim a humanitarian identity-but the exclusion of refugees and immigrants will not solve that particular problem.

This "solution" unfortunately, misses the true link between refugees and security. In the process, it also gives support to racist and xenophobic ideas, although this risk may not have been realised, since these thinkers also suggest that" securitizing" immigration is not necessarily a useful approach. ${ }^{7}$ However, to recognize the potential abuse to which such theorising lends itself is not sufficient: one needs to go further, both by pursuing the question of where exactly the security issue lies in refugee movements, and by developing further the theoretical notion of society as a useful concept in security thinking. Given the space available here, the scope of this article will be restricted to theformer. ${ }^{8}$

A more appropriate approach to the question of how migration and security may be linked, and particularly where the link enters from a refugee perspective, would be to consider the sort of threats and violations of security that refugees face, which (in realist terms) force them out from the protection of their state of origin. In migration studies terms, this does not necessarily return us to unresolved "root causes" debate. Rather, it prompts us to pose questions about the linkages between the causes of forced migration, the type of protection offered to refugees, and the locus of challenge to the protecting $\mathrm{s}$ tate in refugee situations.

The whole point of creating refugee law was always to develop a form of protection for people who had lost the protection of their state of origin. ${ }^{9}$ That is what differentiates economic migrants from refugees: an economic migrant still has the citizenship and protection of his or her state of origin; a refugee enjoys no such protection. Enjoying no such protection, those forced to flee should have the right to" seek and enjoy asylum in countries other than their own."lO The views expressed in academic terms by the Copenhagen School, and those expressed politically both by extreme right-wing parties and, increasingly, by mainstream parties (and not only those of the right), mean that in practice, those displaced by conflicts such as that in Kosovo cannot realize this rightto seek and enjoy asylum, or even forms of protection which accord them fewer rights than asylum does, in countries further away than the states bordering their country of origin. 11

In such a situation, the internally displaced or "refugees" do indeed become part of a heightened security situation. This is not because of who they

Refuge, Vol. 18, No.3 (August 1999) 
are as individuals or, necessarily, because of their position as a group with any particular religious or ethnic identity, which may tip the "balance" of a population, causing additional minority tensions. Rather, it is because, in a mass exodus situation such as that from Kosovo from March to June 1999, the neighbouring states, which are often poor-as indeed both Albania and Macedonia (FYROM) are, cannot efficiently or sufficiently protect the refugees. Perhaps the only protection they can offer is that of non-refoulement. ${ }^{12}$ They cannot provide the shelter, the travel documents, the food required by refugees; they cannot support the refugees' rights to employment and education and, if employment is found, they cannot collect the taxes, of those who seek asylum within their borders. They cannot because they lack the capaCity to do so. One result of this incapacity may be various forms of societal unrest, among the "refugees" and among the host population.

However, the "refugees" do not threaten the stability of those neighbouring states. The threat comes from the state of origin which ceased to protect the people concerned, and from the wider community of states which refuses to live up to its obligations to offer protection to those who are denied the normal protection of their state of origin. The further threat, for the whole international community, is that keeping the "refugees" close to their state of origin only encourages a geographic widening of the conflict-either when fighters among the refugees (in the Kosovars' case, the KLA-Kosovo Liberation Army) continue to fight across the border or use the border "refugee" camps as bases, or when the forces in the state of origin continue their attacks on the fleeing population across an internationally recognised frontier. In either case, this security threat would clearly be avoided if the "refugees" were not only permitted, but if they were encouraged, to move to protection further away. It is of course convenient, under the circumstances, that KosovarAlbanians have often been heard to claim that they do not want to move far from

Refuge, Vol. 18, No.3 (August 1999) home. For many this may be true, but it is clearly not for those who, to seek the protection they need and deserve, have surrendered all their remaining goods and money to human smugglers. The fact that "refugees" need to turn to smugglers only reinforces all the security arguments around this issue. But if their human rights were being respected by ED states, there would be no need for them to buy the services of a smuggler, orto bribe their way up the list of evacuees on the minimal quotas which were established.

A further argument for suggesting that Kosovo's "refugees" should have been accepted, welcomed and protected in greater numbers in ED states is that those very states had intervened in the crisis prior to the cross-border movement of most of the displaced. Their displacement was not necessarily directly or even indirectly caused by the NATO bombs. However, the intervention by NATO statesproclaimed as being motivated by humanitarian concerns, pure and simple-implied a morally unavoidable duty to protect those humans whose suffering the outside states were already seeking to alleviate by their use of force in what they called a just cause. $^{13}$ Besides living up to their humanitarian claims, NATO and ED states would then have been in a position to counter Milosevic's ethnic cleansing (in terms of displacement) by ensuring that a minimum oJ ethnic killing could take place, and by demonstrating how tolerant of ethnic differences their own societies are. Instead, using the ethnic cleansing argument, ED states demonstrated their (perhaps pragmatic, perhaps not) belief that their societies are as intolerant as President Milosevic and his followers-even if, in general, they are not quite so violent in their expressions of racism and xenophobia.

If one considers the various potential and real objects of security, and asks what is threatening in a situation such as the crisis in and around Kosovo in 1999 and before, one arrives, I would suggest, at a common cause for all security concerns. What was the threat to regional and international security?
Intolerance by the Serbian regime. What was the threat to the human and individual security of the KosovarAlbanians? Intolerance by the Serbian regime. What was the threatto the societal security of the "autonomous" region of Kosovo? Intolerance by the Serbian regime. What was the threat to the societal security of Albania and Macedonia? Intolerance by the Serbian regime. What possible threat was there to ED, and individual member states"' societal security"? Intolerance by the Serbian regime. In this last case, one could add the intolerance of racists and xenophobes, just as in the penultimate case one could add, for Macedonia, the intolerance of the local Slav community. However, the individual refugees or groups of refugees themselves posed, in general, no threat. Some of them may be people who would seek to abuse the hospitality of a protecting state. But the vast majority, rather than representing a threat, are the victims of threats and more: they are the victims of intolerance, which seems to be their lot almost everywhere they turn .•

\section{Notes}

1. I am reluctant to use the word "refugee" without inverted commas, to indicate that, while everyday language describes the Kosovar-Albanians now, collectively, as refugees, there are very few who in fact are fortunate enough to have their right to enjoy this status recognised. A refugee is someone who is granted the full protection as agreed upon under various international instruments, including the 1951 Convention relating to the Status of Refugees and the European Convention on Human Rights. Either a state or the UNHCRmust recognize a person as a refugee, granting protection to someone who no longer enjoys, or cannot enjoy, the protection of their state of origin. Such protection has been granted to very few of those escaping the violence in Kosovo; thus, the people involved are not, strictly speaking, refugees, but rather are displaced persons or, in some cases, people with temporary protection. This point is not petty, as it gets to the heart of the security questions surrounding "refugees": what security do these members of global society have if no state will recognize them as refugees?

2. Many refugees do, in fact, return to their country of origin, even if this does not always take place within a short period of 
time after the resolution of the cause of their flight. A great many Chileans who fled in the 1970s returned in the late 1980s and early 1990s. Likewise, programs of return such as that in Mozambique resulted in a high number of repatriations.

3. The key "products" of the "Copenhagen School" are: B. Buzan, M. Kelstrup, P. Lemaitre, E. Tromer, and O. Waever, The European Security Order Recast: Scenarios for the Post-Cold War Era (London: Pinter, 1990); B. Buzan, People, States and Fear: An Agendafor International Security Studies in the Post-Cold War Era (Hemel Hempstead:

Harvester Wheatsheaf, 1991,2nd edition); O. Waever, B. Buzan, M. Kelstrup, and P. Lemaitre, Identity, Migration and the New Security Agenda in Europe (London: Pinter, 1993) and B. Buzan, O. Waever, and J. de Wilde, Security: A New Framework for Analysis (London: Lynne Reiner, 1998).

4. See M. Shaw, Global Society and International Relations (London: Polity, 1994),101.

5. Waever, et al., Identity, Migration op op. cit., 19.
6. See R. Cox, "Social Forces, States and World Orders: Beyond International Relations Theory," Millennium 10, no. 2 (1981) on the distinction between problem solving and cri tical theories.

7. J. Huysmans, "The Question of the Limit: Desecuritisation and the Aesthetics of Horror in Political Realism," Millennium 27, no. 3 (1998).

8. A start to critical security thinking has been made in, e.g., K Krause, and M. Williams, (eds.), Critical Security Studies: Concepts and Cases (London: UCL, 1997). However, where the migration issue is concerned, there remains a long way to go.

9. See,e.g.,G.S.Goodwin-Gill, The Refugee in International Law (Oxford: OUP, 1996 2nd edition); A. Zolberg, A. Suhrke, and S. Aguayo, Escape from Violence: Conflict and the Refugee Crisis in the Developing World (Oxford: OUP, 1989); J. Hathaway, The Law of Refugee Status (Toronto:

Butterworths, 1991); G. Loescher, and L.
Monahan, (eds.) Refugees and International Relations (Oxford: OUP, 1990).

10. Article 14, Universal Declaration of Human Rights.

II, See J. van Selm -Thorburn, Refugee Protection in Europe: Lessons of the Yugoslav Crisis (The Hague: Kluwer Law International, 1998) for details of other protection categories, and particularly temporary protection as granted to Bosnians in various EU states. Temporary protection is here placed in the context of a comprehensive approach, including security issues and humanitarian intervention.

12. Non-return: Article330fthe 1951 Convention.

13. See M. Walzer, Spheres of Justice: A Defence of Pluralism and Equality (Oxford:

Blackwell, 1985); and M. Walzer, Just and Unjust Wars: A Moral Argument with Historical Illustrations (New York: Basic Books, 1992, 2nd edition) for strong ethical reasoning for this position. $\mathrm{Ll}$

\title{
FORCED MIGRATION review
}

published by the Refugee Studies Programme (RSP) in association with the Global IDP Survey

\section{Special issue on Kosovo,}

\author{
due out September 1999 \\ Guest-edited by Matthew Gibney (RSP)
}

This special issue reviews regional security, intervention, ethics, assistance, exile $\&$ internal displacement, return and coordination, and assesses the implications for forced migration in the future.

$$
\begin{aligned}
& \text { with articles by: Nicholas Morris (UNHCR), Richard Caplan (Oxford University), } \\
& \text { Peter Marsden (British Refugee Council), Samantha Guy (Marie Stopes Int), } \\
& \text { Roberta Cohen 8c David Korn (Brookings Institution), Toby Porter (Oxfam), } \\
& \text { Michael Barutciski (RSP) and Alice Bloch (Goldsmith College). }
\end{aligned}
$$

plus regular features: debate, updates, publications, conference reports,

research updates, and news from the Refugee Studies Programme and the Global IDP Survey.

\section{Subscriptions: \\ FREE for}

'developing' countries

students/unwaged

refugees/IDPs

$£ 15 /$ US $\$ 26$

individual

$£ 25 /$ US $\$ 43$

institution

To subscribe or to order a free sample copy, contact the Editors at

Forced Migration Review, RSP, QEH, 21 St Giles, Oxford OX1 3LA, UK.

Email: fmr@qeh.ox.ac.uk • Tel: +44 (0)1865 280700 (fax: 270721) or visit our web pages at www.qeh.ox.ac.uk/rsp/ 


\section{REpORTS}

- Somali Refugees in Toronto: A Profile

By Edward Opoku-Dapaah, 1995 ISBN I-55014-278-x, 130 pp., \$12.95.

This is the first comprehensive study of Somali refugees in Toronto. It examines the social, residential, and linguistic characteristic of Somalis, their participation in the local economy, and the activity of Somali community organizations. The report also contains valuable suggestions and recommendations concerning suitable and more efficient service delivery to this community.

- Cambodian Refugees in Ontario: An Evaluation of Resettlement and Adaptation

By Janet Mclellan, 1995

ISBN 1-55014-267:4, 142 pp., \$12.95.

This major study of Cambodian refugees in Ontario examines the effects of various forms of sponsorship on Cambodian resettlement. It also focuses and the linguistic, economic, educational, training and social dimensions of the whole process of adaptation. The delivery of services by governmental and NGO agencies as well as the effects of the past traumatic experiences of genocide and mass starvation on Cambodian refugees are fully discussed.

- Refugee Families and Children:

A Directory for Service Providers in Metro Toronto

Compiled by

John Morris and Lydia Sawicki, 1995

ISBN 1-55014-285-2, 39 pp., \$6.95.

This directory is designed for service providers who work with refugee families and children in Metro Toronto. Its aim is to improve service provision through networking and the sharing of training opportunities.

Available from:

Centre for Refugee Studies

Refuge, Vol. 18, No. 3 (August 1999)
Back Issues of Refuge, Canada's periodical on refugees

1. Environmental Refugees, Vol. 12, No. 1, June 1992.

2. Discussion of Immigration Bill C-86, Vol. 12, No. 2, July/(August) 1992.

3. General Issue/Refugee Sponsorship, Vol. 12, No. 3, Sept. 1992.

4. Eastern European Refugees, Vol. 12, No. 4, Oct. 1992.

5. The Tragedy of Somalia, Vol. 12, No. 5, November/December 1992

6. The Review of Rejected Refugee Claims in Canada, Vol. 12, No. 6, January 1993.

7. Russia and Central Eurasia, Vol. 12, No. 7, February 1993.

8. Africa Issue: Repatriation, Vol. 12, No. 8, March 1993.

9. General Issue/Globalization, Vol. 13, No. 1, April 1993.

10. Russia and Central Eurasia, Vol. 13, No. 2, May 1993.

11. Special Issue on Sri Ianka Vol. 13 No. 3, June 1993.

12. Gender Issues and Refugee Law, Vol. 13, No. 4, July/August 1993.

13. Southeast Asian Refugees, Vol, 13, No. 5, Sept. 1993.

14. Southeast Asian Refigees, Vol. 13, No. 5 , Sept 1933 .

15. Russia and Central Eurasia, Vol. 13, No. 7, November/December 1993

15. Russia and Central Eurasia, Vol. 13, No. 7, November Issue/Sudan, Vol. 13, No. 8, January 1994.

16. General Issue/Sudan, Vol. 13, No. 8, January 1994.
17. Integration of Refugees-The Canadian Experience, Vol. 13, No. 9, February 1994.

17. Integration of Refugees-The Canadian Experience, Vol. 13, No. 9, Febra

19. Horn of Africa, Vol. 14, No. 1, April 1994.

20. The Russian Federation, Vol. 14, No. 2, May 1994.

21. The Former Yugoslavia, Vol. 14, No. 3, June/July 1994

22. General Issue/IRB and Rebuilding Trust/Tamil Immigrants in Canada Vol. 14, No. 4, August/September 1994.

23. Rwandan Crisis, Vol. 14, No. 5, October 1994

24. Refugee Resettlement in Israel, Vol. 14, No. 6, November 1994.

25. Refuge Women-Part 1: Issues, Vol. 14, No. 7, December 1994

26. Refugee Women-Part 2: Case Studies, Vol. 14, No. 8, January 1995.

26. Refugee Women-Part 2: Case Studies, Vol. 14, No. 8, January

27. The Safe Third Country Concept, Vol. 14, No. 9, Februar
28. Special Issue on Chechnya, Vol. 14, No. 10, March 1995.

29. Reformulation of International Refugee Law, Vol. 15, No. 1, 1996

29. Reformulation of International Refugee Law, Vol. 15, No. 1, 1996.

31. International Intervention in Refugee Crises, Vol. 15, No. 3, 1996

32. Early Warning on Humanitarian Crises, Vol. 15, No. 4, 1996.

33. Child Refugees, Vol. 15, No. 5, 1996.

34. Global Settlement Services, Vol. 15, No. 6, 1997

35. Early Warning and Early Response, Vol. 16, No. 1, May 1997.

36. Uprooting and Consequences, Vol. 16, No. 2, June 1997.

37. Development-induced Displacement, Vol. 16, No. 3, August 1997.

38. Refugee and Immigrant Women: An International Perspective, Vol. 16, No. 4 , October 1997.

39. Working with Refugees and Internally Displaced Persons, Vol. 16, No. 5, Nov. 1997.

40. Conflict, Population Displacement, and Conflict Resolution, Vol. 16, No. 6, Dec. 1997

41. Refugee and Immigrant Women: An International Perspective, Part II, Vol. 17, No. 1 February 1998.

42. Human Rights and Refugee Movements in the Newly Independent States of the Former Soviet Union, Vol. 17, No. 2, April 1998.

43. Current Issues in Refugee and Human Rights Policy and Research, Vol. 17, No. 3 , August 1998.

44. Violent Displacement and Post-Conflict Reconstruction: Afghanistan, Uganda, and Rwanda, Vol. 17, No. 4, October 1998.

45. New Cargo: The Global Business of Trafficking in Women, Vol. 17, No. 5, Nov. 1998.

46. Critical Perspectives on Refugees, Vol. 17, No. 6, December 1998.

47. Not Just Numbers and New Directions: Implications for Canadian Refugee Policy, Vol. 18 No. 1, February 1999

47. Conflict, Human Rights, and Integration of Refugees, Vol. 18, No. 2, April 1999 Single copy: Vol 12, $13 \& 14-\$ 6.50$; Vol 15, 16, 17-\$10. 10 percent discount on 3-9 issues (copies); 20 percent discount on 10 issues (copies) or more. Special discounts are available for students and exclusively volunteer-run NGOs. P. O. accepted.

Please send your orders to:

Centre for Refugee Studies, York University

Suite 333, York Lanes, 4700 Keele Street, Toronto, Ontario, Canada M3J 1P3

Fax: (416) 736-5837・ Email: refuge@yorku.ca • mswinder@yorku.ca 
Refuge Centre for Refugee Studies Suite 322, York Lanes York University 4700 Keele Street, Toronto Ontario, Canada M3J 1P3 Phone: (416) 7365663 Fax: (416) 736-5837 Emai1: refuge@yorku.ca

\section{Tile, Other SIde of the Equation: North American 1rafficking in Women and Children}

Guest Editor: Marilou McPhedran Project Director International Women's Rights;

Director, CEDAW Impact Study; Centre for Feminist Research, York University

(A guest editorial board of advocates working in this fieU is being assembled.)

Having presented first hand accoun of trafficking in women in many developing countries in the November 1998 issue of Refuge, we have received positive feedback on this "first voice" approach and requests for more information about the consumers of the "new cargo"-trafficked women and children. To do this we shall focus closer to home: North America. Thus, this issue will bring systemic analysis to the realicy of trafficking (including forced labour) in Canada, the USA and Mexico, as well as the role of trafficking operations with North American managers and promoters, both in North America and in other countries.

This issue of Refuge will address topics such as:

- Historical background of trafficking in women and children to North America;

- The root causes of trafficking, including economic displacement and economic "benefits";

- The consumers of the "new cargo" trafficked women and children;

- The roles of governments, national and international organizations, including media and corporations,

in raising wareness to the problem, and developing preventive strategies;

- Personal accounts and analysis;

- Gender based analysis and agewbased analysis; and

- Genderwspedfic and agewspecific strategies.

Contributions with abstracts are invited. They must be received no later than December 15, 1999. Papers should be typed, double spaced, and referenced.in the. academic format. They should not exceed 16 pages or about 4000 words. Short pa s of about ?OO..words,atealsp ,!elcome;.. ordwprocessed submissions may be sent on disc or byew maiL On a:-11t , aussi IUS articles enftan;ais. Leltj ::doit co former aux normes exiges pour us articles rMiges en anglais.

Deadline: December 15, 1999.

$P ; r \quad$ [u.rtherdefails. please

ff)llfacf: Marilou McPhedran, Guest Editor, Refuge Centre for Feminist Research, York University, 4700 Keele Street, Toronto, Ontario, Canada M Fax: (416) 736-5416 - Tel.: (416) 736-5915

-

refuge@yorku.ca 